\title{
Nurses' knowledge to identify early acute kidney injury
}

\author{
Conhecimento do enfermeiro para identificação precoce da injúria renal aguda \\ Conocimiento del enfermero para la identificación precoz de la insuficiencia renal aguda
}

Roseli Aparecida Matheus do Nascimento ${ }^{1}$, Murillo Santucci Cesar Assunção², João Manoel Silva Junior ${ }^{3}$, Cristina Prata Amendola ${ }^{4}$, Taysa Martindo de Carvalho ${ }^{4}$, Emerson Quintino Lima ${ }^{1}$, Suzana Margareth Ajeje Lobo ${ }^{1}$

How to cite this article:

Nascimento RAM, Assunção MSC, Silva Junior JM, Amendola CP, Carvalho TM, Lima EQ, et al. Nurses' knowledge to identify early acute kidney injury. Rev Esc Enferm USP. 2016;50(3):399-404. DOI: http://dx.doi.org/10.1590/S0080-623420160000400004

\author{
${ }^{1}$ Faculdade de Medicina de São José do Rio \\ Preto, São José do Rio Preto, SP, Brazil. \\ ${ }^{2}$ Universidade Federal de São \\ Paulo, São Paulo, SP, Brazil. \\ ${ }^{3}$ Hospital do Servidor Público \\ Estadual, São Paulo, SP, Brazil. \\ ${ }^{4}$ Hospital do Câncer, Barretos, SP, Brazil.
}

\begin{abstract}
Objective: To evaluate the knowledge of nurses on early identification of acute kidney injury (AKI) in intensive care, emergency and hospitalization units. Method: A prospective multi-center study was conducted with 216 nurses, using a questionnaire with 10 questions related to AKI prevention, diagnosis, and treatment. Results: $57.2 \%$ of nurses were unable to identify AKI clinical manifestations, 54.6\% did not have knowledge of AKI incidence in patients admitted to the ICU, $87.0 \%$ of the nurses did not know how to answer as regards the AKI mortality rate in patients admitted to the ICU, $67.1 \%$ answered incorrectly that slight increases in serum creatinine do not have an impact on mortality, $66.8 \%$ answered incorrectly to the question on AKI prevention measures, $60.4 \%$ answered correctly that loop diuretics for preventing AKI is not recommended, $77.6 \%$ answered correctly that AKI does not characterize the need for hemodialysis, and 92.5\% said they had no knowledge of the Acute Kidney Injury Network classification. Conclusion: Nurses do not have enough knowledge to identify early AKI, demonstrating the importance of qualification programs in this field of knowledge.
\end{abstract}

DESCRIPTORS

Acute Kidney Injury; Nursing Care; Knowledge; Early Diagnosis; Training.

Corresponding author:

Suzana Margareth Ajeje Lobo

Faculdade de Medicina de São José

do Rio Preto, Hospital de Base

Av. Brigadeiro Faria de Lima, 5416

CEP 15090-000 - São José do Rio Preto, SP, Brazil

suzanaalobo@gmail.com 


\section{INTRODUCTION}

Acute kidney injury (AKI) is a serious manifestation caused by multiple and varied etiologies related to a high mortality rate and the extended length of hospital stay ${ }^{(1)}$. It may be present in the community and in hospital settings. Sepsis is the most common cause of AKI in critical patients and is associated with higher severity, increasing risk of death and hospital admissions, compared to non-septic patients ${ }^{(2)}$. In intensive care units (ICU), its incidence may reach $20 \%$, and $49 \%$ to $70 \%$ of patients need dialytic treatment ${ }^{(3-4)}$.

It is very difficult to establish AKI incidence due to the lack of a standard definition ${ }^{(3)}$. Experts from an international network proposed a new AKI definition and classification, the Acute Kidney Injury Network (AKIN), with the aim of standardizing this concept for clinical study purposes and, particularly, facilitating the diagnosis of this syndrome, in an attempt to reduce high morbidity and mortality still currently found ${ }^{(5-6)}$.

In view of the high mortality associated with the presence of AKI, the possibility of detecting risk factors and the implementation of preventive measures make the work of health professionals more critical for early identification ${ }^{(7)}$. The lack of properly trained professionals aware of the problem may delay the detection and referral to specialized services, leading to worse results ${ }^{(1-8)}$.
The work of nurses is very important for the health multidisciplinary team with attention provided to risk factors and early diagnosis, as well as preparing the infrastructure for carrying out hospital procedures in an efficient and safe manner. The objective of this study was to evaluate the knowledge of nurses on early identification of AKI in intensive care, emergency and hospitalization units.

\section{METHOD}

A cross-sectional, descriptive, multi-center, quantitative, and prospective study was conducted in six public and private hospitals. The hospital selection process to participate in the study was determined by the possibility of contacting the coordinators of the participating ICUs and the characteristics of the hospitals. Once the research proposal was approved by the Research Ethics Committee of Faculdade de Medicina de São José do Rio Preto (FAMERP), under protocol number 5188/2010, a questionnaire was applied to 216 nurses working in intensive care, emergency and hospitalization units, who were available at the workplace between October 2010 and February 2011. A pilot questionnaire was designed with 10 multiple choice questions, based on the literature on the topic and according to experience in ICU care practice (Chart 1).

Chart 1 - Questionnaire - São José do Rio Preto, SP, Brazil, 2015.

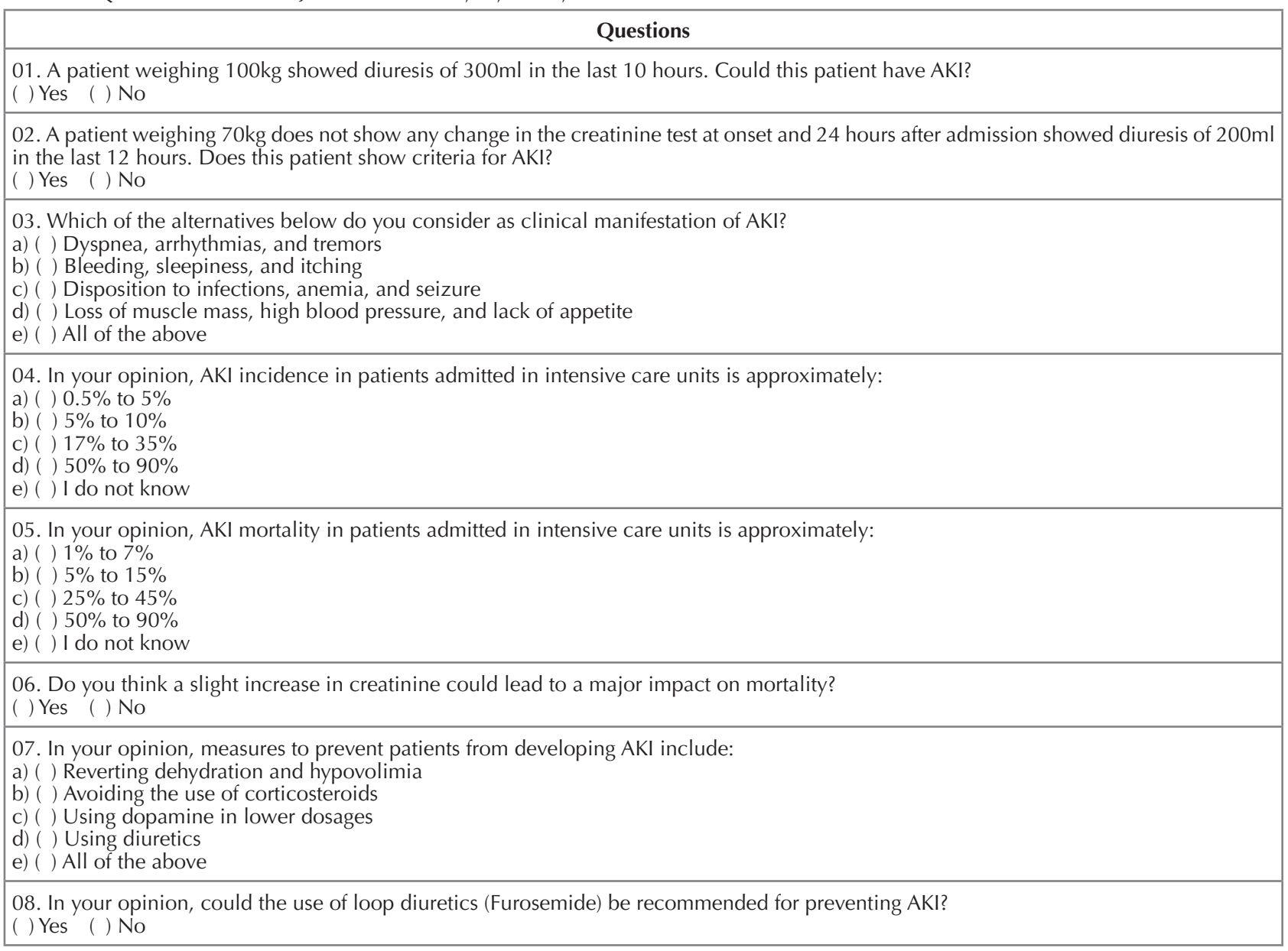


09. In your opinion, is AKI characterized by the need for hemodialysis? ( ) Yes ( ) No

10. Do you know the AKIN classification?

( ) Yes ( ) No

The tool was submitted for validation by six nurses working in intensive care, emergency and hospitalization units, who were individually instructed for carrying it out. Thus, the group of experts judged six aspects, and each one graded them based on seven levels of quality, varying from "unacceptable" up to "very good". The questionnaire was validated with $75 \%$ of approval at the "good" level for each one of the aspects proposed to test ${ }^{(9)}$.

The questionnaires were sent out and returned by mail to each participating institution. The participating hospital institutions were identified as public and private or both.

\section{RESULTS}

A total of 216 nurses participated in the study, with the aim of identifying their knowledge on early AKI identification. The mean age of the participants was $31.0 \pm 6.1$ years, ranging from 22 to 53 years, and most were women (84.8\%). Length of profession varied from less than 1 year to 15 years, with a higher percentage (70.1\%) of professionals showing more than 5 years since graduation.

Regarding the sector of activity, 215 nurses answered the questionnaire. Of these, 131 (60.9\%) worked in an intensive care unit; 55 (25.6\%) in a hospitalization unit, 26 (12.1\%) in an emergency unit, and $3(1.4 \%)$ worked in more than one sector. Nursing specialization was also questioned in the sample characterization study. Of all 216 nurses who answered this question, $161(74.5 \%)$ were specialists, $4(1.9 \%)$ held a master's degree, $1(0.5 \%)$ held a Ph.D., and $50(23.1 \%)$ held no degree.

Regarding experience in unit with nephrological patients, 95 nurses (44\%) had already worked with this kind of patient, being that 20 nurses (21\%) worked for less than a year, 34 nurses (36\%) worked from 1 to 13 years, and 41 nurses (43\%) worked for approximately 3 to 5 years.

Figure 1 shows the rate of right answers to questions related to the respondent nurses. Of 213 nurses who answered question 1,174 (81.7\%) answered correctly that the situation characterized an AKI diagnosis.

Question 2 showed a situation in which a patient weighing $70 \mathrm{~kg}$ did not show any change in the creatinine test. 24 hours after admission, however, the patient showed only $200 \mathrm{~mL}$ of diuresis in a period of 12 hours. The nurses were asked whether this patient showed criteria for AKI. Of the total 211 respondents, 135 (64.0\%) answered “yes" and got the answer right.

The third was a multiple choice question and asked nurses about AKI clinical manifestations. All the alternatives listed were right. There was a higher percentage of error in this question (57.2\%).

As for question 4, regarding AKI incidence in patients admitted to the ICU, the correct answer was the one that showed a $17 \%$ to $35 \%$ incidence. The percentage of nurses who got it wrong was $54.6 \%$.

For question 5, which referred to mortality incidence in AKI patients admitted to the ICU, the correct answer was the one that showed $50 \%$ to $90 \%$ incidence. Of a total of 216 respondents, 28 (13.0\%) answered correctly.

Question 6 addressed whether a slight increase in creatinine level could lead to a major impact on mortality. The correct answer would be "yes", however, 143 (67.1\%) answered "no".

Question 7 evaluated knowledge on important measures for preventing AKI. The right answer showed that these measures involve reverting dehydration and hypovolimia. Of 214 respondents, only $33.2 \%$ answered correctly.

The $8^{\text {th }}$ question asked whether the use of loop diuretics (Furosemide) is recommended for preventing AKI. The right answer is negative. Of 213 respondents, 128 (60.4\%) answered correctly.

The $9^{\text {th }}$ question addressed the need for hemodialysis in AKI characterization. Of 214 respondents, 166 (77.6\%) answered that there was no need for hemodialysis and got it right.

Question 10 evaluated knowledge on the AKIN classification. Of 212 respondents, 196 (92.4\%) answered they did not have knowledge on this classification.

Tables 1 and 2 show the percentage of right answers, according to the work sector and time since graduation, respectively. Table 3 shows the percentage of right answers according to public and private institutions. As for question 4, on AKI incidence, the nurses who work in public hospitals had a higher percentage of right answers in relation to the nurses who work in private hospitals ( $49.7 \%$ vs. $31.5 \%)(\mathrm{p}=0.023)$. However, it should be noted that in both institutions less than $50 \%$ of all nurses were able to indicate a variation in AKI mortality rates. As for knowledge on the AKIN classification, in question 10, the nurses who work in private hospitals had more knowledge in relation to the nurses from public hospitals (14.0\% vs. $5.6 \%)(\mathrm{p}=0.08)$.

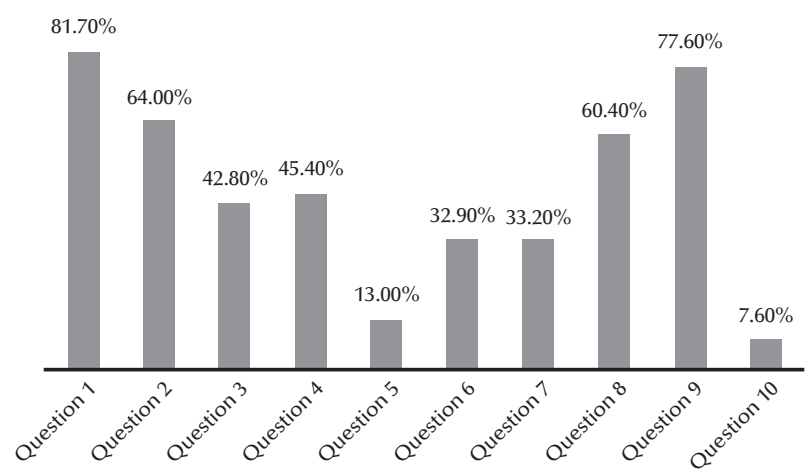

Figure 1 - Rate of right answers by respondent nurses - São José do Rio Preto, SP, Brazil, 2015. 
Table 1 - Percentage of right answers according to work sector São José do Rio Preto, SP, Brazil, 2015.

\begin{tabular}{lccc}
\hline Questions & Intensive care & Hospitalization & Emergency \\
\hline 1 & $103(80.5)$ & $44(80.0)$ & $24(92.3)$ \\
2 & $76(59.4)$ & $36(66.7)$ & $21(84.0)^{*}$ \\
3 & $51(40.8)$ & $25(46.3)$ & $11(44.0)$ \\
4 & $57(43.5)$ & $55(41.8)$ & $15(57.7)$ \\
5 & $16(12.3)$ & $08(14.8)$ & $03(11.5)$ \\
6 & $40(31.0)$ & $18(32.8)$ & $09(36.0)$ \\
7 & $41(31.8)$ & $19(34.5)$ & $09(34.6)$ \\
8 & $73(57.0)$ & $33(61.1)$ & $20(76.9)^{*}$ \\
9 & $96(75.0)$ & $42(76.4)$ & $25(96.2)^{*} \#$ \\
10 & $13(9.9)$ & $03(5.4)$ & $01(3.8)$ \\
\hline
\end{tabular}

*P $<0.05$ vs. Intensive care unit.

$\# \mathrm{P}<0.05$ vs. Hospitalization unit.

Table 2 - Percentage of right answers according to time since graduation in years - São José do Rio Preto, SP, Brazil, 2015.

\begin{tabular}{lcc}
\hline Questions & $<$ from $\mathbf{1}$ to $\mathbf{4}$ years & $\mathbf{5}$ to $\mathbf{1 5}$ years \\
\hline 1 & $52(83.9)$ & $118(80.8)$ \\
2 & $37(59.7)$ & $93(63.3)$ \\
3 & $18(29.0)$ & $66(45.2)$ \\
4 & $52(83.9)$ & $118(80.8)$ \\
5 & $06(9.7)$ & $48(32.9)$ \\
6 & $18(29.0)$ & $54(37.0)$ \\
7 & $19(30.6)$ & $51(34.9)$ \\
8 & $38(61.2)$ & $88(60.3)$ \\
9 & $41(66.1)$ & $117(80.1)$ \\
10 & $05(8.0)$ & $10(6.8)$ \\
\hline
\end{tabular}

Table 3 - Percentage of right answers according to public or private institution - São José do Rio Preto, SP, Brazil, 2015.

\begin{tabular}{lcc}
\hline Questions & \multicolumn{1}{c}{ Public } & Private \\
\hline 1 & $129(81.1)$ & $45(78.9)$ \\
2 & $103(64.8)$ & $32(56.1)$ \\
3 & $66(41.5)$ & $27(47.3)$ \\
4 & $79(49.7)$ & $18(31.5)^{*}$ \\
5 & $28(17.6)$ & $02(3.5)$ \\
6 & $53(33.3)$ & $17(29.8)$ \\
7 & $50(31.4)$ & $21(36.8)$ \\
8 & $89(55.9)$ & $31(54.3)$ \\
9 & $122(76.7)$ & $44(77.1)$ \\
10 & $09(5.6)$ & $08(14.0)^{*}$ \\
\hline
\end{tabular}

${ }^{*} \mathrm{P}<0.05$ vs Private.

\section{DISCUSSION}

This study showed that the knowledge of nurses who work in hospitalization, emergency, and intensive care units in public and private hospitals as regards AKI diagnosis, prevention, and clinical signs is not adequate.
Some studies measured the knowledge of nurses on topics such as the systematization of nursing care ${ }^{(10)}$, drug administration via nasogastric and nasoenteral feeding tubes $^{(11)}$, hand hygiene ${ }^{(12)}$, diabetes ${ }^{(13)}$, and anticoagulation and atrial fibrillation ${ }^{(14)}$. However, no study related to AKI identification was found.

The service provided by hospitals to high risk patients, such as those with multiple trauma, submitted to complex surgeries, organ transplants, and with acute and chronic diseases of varied etiologies that can lead to AKI has been on the rise; thus suggesting the need for fast and specialized first aid service to these patients in order to prevent the development of kidney failure. The evaluation of the qualification of health professionals in specific areas of knowledge can signal to the need for implementing continuing education measures that can improve clinical care. Due to its major impact on the evolution of high risk patients and the possibility of adopting a series of preventive measures when a risk is detected, AKI is, without a doubt, an area that must be researched on risk perception and general knowledge in sectors where this syndrome has higher rates.

The answers of nurses as regards public or private hospitals, considering the questions as a whole (from 1 to 10), did not show a significant difference. However, separately, questions 1, 2, 8, and 9, which addressed AKI diagnosis and treatment showed a mean of right answers above $50 \%$ in both institutions, whereas questions 5 and 10 on mortality rate and knowledge on the AKIN classification had less than $20 \%$ of right answers. The level of knowledge of the nurses was similar, regardless of their institution being public or private. In relation to their length of profession, there was no significant difference, since they had similar right answer rates. This finding indicates the possibility of a curricular deficiency in nursing undergraduate education, lack of continuing education programs for nurses already graduated for a long time or work overload with less time dedicated to updating and studying.

Data drawn from other studies suggest knowledge deficits in other areas, including a systematic review regarding knowledge on diabetes ${ }^{(10-13)}$. A study that included nurses from different countries showed significant deficiencies in several aspects of care to diabetic patients ${ }^{(13)}$. When nurses start working in hospital units, they are faced with the need for taking over several administrative and care tasks and functions with an extensive weekly workload and, often, with several employment bonds, which can keep them away from continuous learning that is so crucial for caring for high-risk patients ${ }^{(15)}$. These data are extremely important for managers, and all of those involved in the undergraduate and continuing education of nursing professionals, for defining and developing strategies for improving their qualification and skills. It is of great interest that knowledge on other strategic areas such as trauma, sepsis, nutritional support, and patient safety be investigated in similar studies.

The limitations of this study involve its sample size and the limited geographical region limited in which it was carried out. In contrast, the sample was diversified, as it included public and private hospitals from different cities and from two states representing the wealthier regions of 
the country, which indicates that the results could be even worse in other states with fewer resources. The use of forms distributed individually by their coordinators among the members of the units was probably a strategy that helped to increase adherence to the questionnaire and the commitment to answering the questions, compared to the currently most used strategies, such as sending through e-mail.

\section{CONCLUSION}

The results showed that most nurses do not hold enough knowledge on early identification of AKI, therefore, there is a need for developing and applying qualification programs with the aim of improving competences and skills for preventing and identifying early AKI.

\section{RESUMO}

Objetivo: Avaliar o conhecimento do enfermeiro na identificação precoce da Injúria Renal Aguda (IRA) em Unidade de Terapia Intensiva, Unidade de Internação e Emergência. Método: Estudo multicêntrico, prospectivo. Participaram do estudo 216 enfermeiros, por meio de questionário com 10 questões relacionadas à prevenção, ao diagnóstico e ao tratamento da IRA. Resultados: $57,2 \%$ não souberam identificar as manifestações clínicas da IRA, 54,6\% não têm conhecimento da incidência de IRA em pacientes internados na UTI, $87,0 \%$ dos enfermeiros não souberam responder ao índice de mortalidade de IRA em pacientes internados na UTI, $67,1 \%$ responderam incorretamente que aumentos discretos da creatinina sérica não têm impacto na mortalidade, $66,8 \%$ responderam incorretamente à questão sobre as medidas de prevenção da IRA, 60,4\% acertaram quando responderam que não é recomendada a utilização de diuréticos de alça na prevenção da IRA, 77,6\% acertaram ao responder que IRA não caracteriza necessidade de hemodiálise e 92,5\% disseram não conhecer a classificação AKIN. Conclusão: Enfermeiros não têm conhecimento suficiente para a identificação precoce da IRA, mostrando a importância de programas de capacitação nesta área do conhecimento.

\section{DESCRITORES}

Lesão Renal Aguda; Cuidados de Enfermagem; Conhecimento; Diagnóstico Precoce; Capacitação.

\section{RESUMEN}

Objetivo: Evaluar el conocimiento del enfermero en la identificación precoz de la Insuficiencia Renal Aguda (IRA) en Unidad de Cuidados Intensivos, Unidad de Estancia Hospitalaria y Urgencias. Método: Estudio multicéntrico, prospectivo. Participaron en el estudio 216 enfermeros, mediante cuestionario con 10 preguntas relacionadas con la prevención, el diagnóstico y el tratamiento de la IRA. Resultados: el 57,2\% no supieron identificar las manifestaciones clínicas de la IRA, el 54,6\% no tienen conocimiento de la incidencia de IRA en pacientes ingresados en la UCI, el 87,0\% de los enfermeros no supieron responder al índice de mortalidad de IRA en pacientes ingresados en la UCI, el $67,1 \%$ respondieron incorrectamente que aumentos discretos de la creatinina sérica no tienen impacto en la mortalidad, el 66,8\% respondieron incorrectamente a la pregunta acerca de las medidas de prevención a la IRA, el 60,4\% acertaron cuando respondieron que no se recomienda la utilización de diuréticos de asa en la prevención de la IRA, el 77,6\% acertaron al responder que la IRA no caracteriza necesidad de hemodiálisis y el 92,5\% dijeron no conocer la clasificación AKIN. Conclusión: Enfermeros no tienen conocimiento suficiente para la identificación precoz de la IRA, mostrando la importancia de programas de capacitación en esa área del conocimiento.

\section{DESCRIPTORES}

Lesión Renal Aguda; Atención de Enfermería; Conocimiento; Diagnóstico Precoz; Capacitación.

\section{REFERENCES}

1. Lewington AJ, Cerdá J, Mehta RL. Awareness of acute kidney injury: a global perspective of a silent killer. Kidney Int. 2013;84(3):457-67.

2. Bagasha P, Nakwagala F, Kwizera A, Ssekasanvu E, Kalyesubula R. Acute kidney injury among adult patients with sepsis in a low-income country: clinical patterns and short-term outcomes. BMC Nephrol. 2015;16:4.

3. Lombardi R, Rosa-Diez G, Ferreiro A, Greloni G, Yu L, Younes-Ibrahim M, et al. Acute kidney injury in Latin America: a view on renal replacement therapy resources. Nephrol Dial Transplant. 2014;29(7):1369-76.

4. Bernardina LD, Diccini S, Belasco AGS, Bittencourt ARC, Barbosa DA. The clinical outcome of patients with acute renal failure in intensive care unit. Acta Paul Enferm. 2008;21(n.spe):174-8.

5. Sociedade Brasileira de Nefrologia; Comitê de Insuficiência Renal Aguda. Insuficiência Renal Aguda: diretrizes. São Paulo: SBN; 2007.

6. Magro MCS, Franco ES, Guimarães D, Kajimoto D, Gonçalves AMB, Vattimo MFF. Evaluation of the renal function in patients in the postoperative period of cardiac surgery: does AKIN classification predict acute kidney dysfunction? Rev Bras Ter Intensiva. 2009;21(1):25-31.

7. Camerini FG, Cruz I. Nursing care in the prevention of renal failure caused by post-catheterism contrast. Acta Paul Enferm. 2008;21(4):660-6.

8. Challiner R, Ritchie JP, Fullwood C, Loughnan P, Hutchison AJ. Incidence and consequence of acute kidney injury in unselected emergency admissions to a large acute UK hospital trust. BMC Nephrol. 2014;15:84

9. Cunha HFR, Salluh JI, França MF. Intensive care physicians' attitudes and perceptions on nutrition therapy: a web-based survey. Rev Bras Ter Intensiva. 2010;22(1):53-63.

10. Silva EGC, Oliveira VC, Neves GBC, Guimarães TMR. Nurses' knowledge about Nursing Care Systematization: from theory to practice. Rev Esc Enferm USP. 2011;45(6):1376-82.

11. Mota MLS, Barbosa IV, Studart RMB, Melo EM, Lima FET, Mariano FA. Evaluation of intensivist-nurses' knowledge concerning medication administration through nasogastric and enteral tubes. Rev Latino Am Enfermagem. 2010;18(5):888-94. 
12. Asadollahi M, Bostanabad MA, Jebraili M, Mahallei M, Rasooli AS, Abdolalipour M. Nurses' knowledge regarding hand hygiene and its individual and organizational predictors. J Caring Sci. 2015;4(1):45-53.

13. Alotaibi A, Al-Ganmi A, Gholizadeh L, Perry L. Diabetes knowledge of nurses in different countries: an integrative review. Nurse Educ Today. 2016;39:32-49.

14. Ferguson C, Inglis SC, Newton PJ, Middleton S, Macdonald PS, Davidson PM. Education and practice gaps on atrial fibrillation and anticoagulation: a survey of cardiovascular nurses. BMC Med Educ. 2016;16:9.

15. Costa RA, Shimizu HE. Atividades desenvolvidas pelos enfermeiros nas unidades de internação de um hospital-escola. Rev Latino Am Enfermagem. 2005;13(5):654-62. 